\title{
A diagenetic model discriminating denitrification and dissimilatory nitrate reduction to ammonium in a temperate estuarine sediment
}

\author{
B. A. Kelly-Gerreyn ${ }^{1, *}$, M. Trimmer ${ }^{2}$, D. J. Hydes ${ }^{1}$ \\ ${ }^{1}$ Southampton Oceanography Centre, Waterfront Campus, European Way, Southampton SO14 3ZH, United Kingdom \\ ${ }^{2}$ School of Biological Sciences, Queen Mary College, University of London, London E1 4NS, United Kingdom
}

\begin{abstract}
A diagenetic model is presented which considers nitrate reduction by both denitrification and Dissimilatory Nitrate Reduction to Ammonium (DNRA). This work builds on an existing model (Kelly-Gerreyn et al. 1999; Mar Ecol Prog Ser 177:37-50). Previous models have assumed nitrate reduction to be solely due to denitrification. This paper questions the reliability of this assumption in coastal areas and suggests that DNRA can account for a high proportion of nitrate reduction. Data from a North Sea estuary (the lower Gt. Ouse, Norfolk, UK) containing high nutrient concentrations (mean $406 \mathrm{\mu M} \mathrm{NO}_{3}{ }^{-}$) are used to derive a relationship between temperature and the proportioning of nitrate reduction driven by nitrate from the overlying water into denitrification and DNRA. The relationship is assumed to apply to total nitrate reduction. The result is a function which shows that DNRA and denitrification occur at all temperatures but that DNRA is the favoured pathway at the extremes of the observed temperatures $\left(<14\right.$ and $\left.>17^{\circ} \mathrm{C}\right)$ while denitrification is favoured only in a narrow range of temperatures $\left(14\right.$ to $\left.17^{\circ} \mathrm{C}\right)$. The mechanism is probably an adaptive response of different nitratereducing bacteria to temperature. This temperature relationship is implemented in the model and used to successfully simulate both observed rates of uncoupled denitrification (4 to $228 \mu \mathrm{molN} \mathrm{m}{ }^{-2} \mathrm{~h}^{-1}$ ), denitrification fuelled by nitrate in the overlying water $\left(D_{\mathrm{w}}\right)$, and calculated rates of DNRA fuelled by nitrate in the overlying water $\left(\mathrm{DNRA}_{\mathrm{w}}\right)$ (measured nitrate flux - measured $D_{\mathrm{w}}$ rate). In contrast, standard diagenetic formulae for nitrate reduction (i.e. by denitrification only) cannot satisfactorily reproduce the $D_{\mathrm{w}}$ rates observed in these sediments. It is concluded that temperature is an important controlling factor for partitioning nitrate reduction into DNRA and denitrification in the lower Gt. Ouse sediments. This temperature effect implies that during an extended warm summer in temperate estuaries receiving high nitrate inputs, nitrate reduction may contribute to, rather than counteract, a eutrophication event. Diagenetic models of the nitrogen cycle in coastal areas should include DNRA.
\end{abstract}

KEY WORDS: Diagenesis model $\cdot$ Denitrification · Dissimilatory nitrate reduction to ammonium · Temperature

\section{INTRODUCTION}

A number of diagenetic models have been developed in recent years (Boudreau 1995, Soetaert et al. 1996, Kelly-Gerreyn et al. 1999) to help improve understanding of sedimentary biogeochemical processes. Some models (Wang \& Van Cappellan 1996) are more complex than others (Kelly-Gerreyn et al.

*E-mail: b.kelly-gerreyn@soc.soton.ac.uk
1999) in terms of the number of processes considered, and yet their underlying formulae for any particular process are the same. In this respect, the nitrogen cycle in all of these models consists of nitrate and ammonium, denitrification and nitrification. Intermediate nitrogenous compounds are neglected mostly due to lack of adequate data. In all of the models mentioned so far, nitrate reduction is treated as denitrification (whether directly coupled to ammonium oxidation as in Soetaert et al. 1996 or not). However, the alternative 
Table 1. Percentage contribution of Dissimilatory Nitrate Reduction to Ammonium (DNRA) to sedimentary nitrate reduction at different locations around the world (ABT = Acetylene Blockage Technique)

\begin{tabular}{|llcl|}
\hline \multicolumn{1}{|c}{ Location } & Method & \multicolumn{1}{c|}{ Source } \\
\hline $7-3$ & Coastal/Estuarine (Tokyo Bay), Japan & ${ }^{15} \mathrm{~N}$ assay + ABT & Koike \& Hattori (1978) \\
56 & Coastal/Marine (Limfjorden), Denmark & ${ }^{15} \mathrm{~N}$ assay + ABT & Sørensen (1978) \\
$5-30$ & Coastal/Intertidal, New Zealand & ${ }^{15} \mathrm{~N}$ assay + ABT & Kaspar (1983) \\
$40-70$ & Coastal/Estuarine, Japan & ${ }^{15} \mathrm{~N}$ assay + ABT & Nishio et al. (1983) \\
$0-18$ & Coastal, New Zealand (South Island) & ${ }^{15} \mathrm{~N}$ assay + ABT & Kaspar et al. (1985) \\
$65-90$ & Estuarine (Norsminde Fjord), Denmark & ABT & Jørgensen \& Sørensen (1985) \\
32 & Coastal/Marine, The Netherlands & ${ }^{15} \mathrm{~N}$ assay + ABT & Goeyens et al. (1987) \\
70 & Estuarine (Norsminde Fjord), Denmark & ABT & Jørgensen \& Sørensen (1988) \\
$4-21$ & Estuarine (Norsminde Fjord), Denmark & ${ }^{15} \mathrm{~N}$ assay + ABT & Jørgensen (1989) \\
97 & Coastal (Hiroshima Bay), Japan & $\mathrm{ABT}+$ estimate of nitrification & Kim et al. (1997) \\
54 & Estuarine (Lower Gt. Ouse), UK & ABT & Trimmer et al. (1998) \\
98 & Coastal Lagoon, France & ${ }^{15} \mathrm{~N}$ assay + ABT & Gilbert et al. (1998)
\end{tabular}

pathway which converts nitrate to ammonium can be a greater component of nitrate reduction in coastal sediments (e.g. Gilbert et al. 1998, Trimmer et al. 1998). This latter component is called Dissimilatory Nitrate Reduction to Ammonium (DNRA).

The ecological significance of these 2 competing processes is that denitrification leads to a loss of nitrogen from the ecosystem while DNRA retains nitrogen in the preferred form for biological uptake. While denitrification has received much attention (e.g. Seitzinger 1988, Middelburg et al. 1996, Hydes et al. 1999), some research, but no modelling, has been carried out on DNRA (e.g. Cole \& Brown 1980, Sørensen 1978). Table 1 shows that DNRA (measured using ${ }^{15} \mathrm{~N}$ assay techniques and/or estimated from measurements of both denitrification using the acetylene blockage technique and nitrate exchange at the sediment water interface) can account for a high proportion of the total nitrate reduction that takes place in sediments. Sørensen (1978) has shown that in organic-rich sediments, DNRA may account for up to one third of the total carbon oxidation.

Microbes capable of nitrate reduction are widely distributed in nature (Cole \& Brown 1980, Tiedje 1988). Hence, any restriction to nitrate reduction will probably be related to environmental conditions that regulate the process rather than to a lack of microorganisms. Consequently, any model of nitrate reduction must account for the effect of the regulating factors. These include temperature (King \& Nedwell 1984,

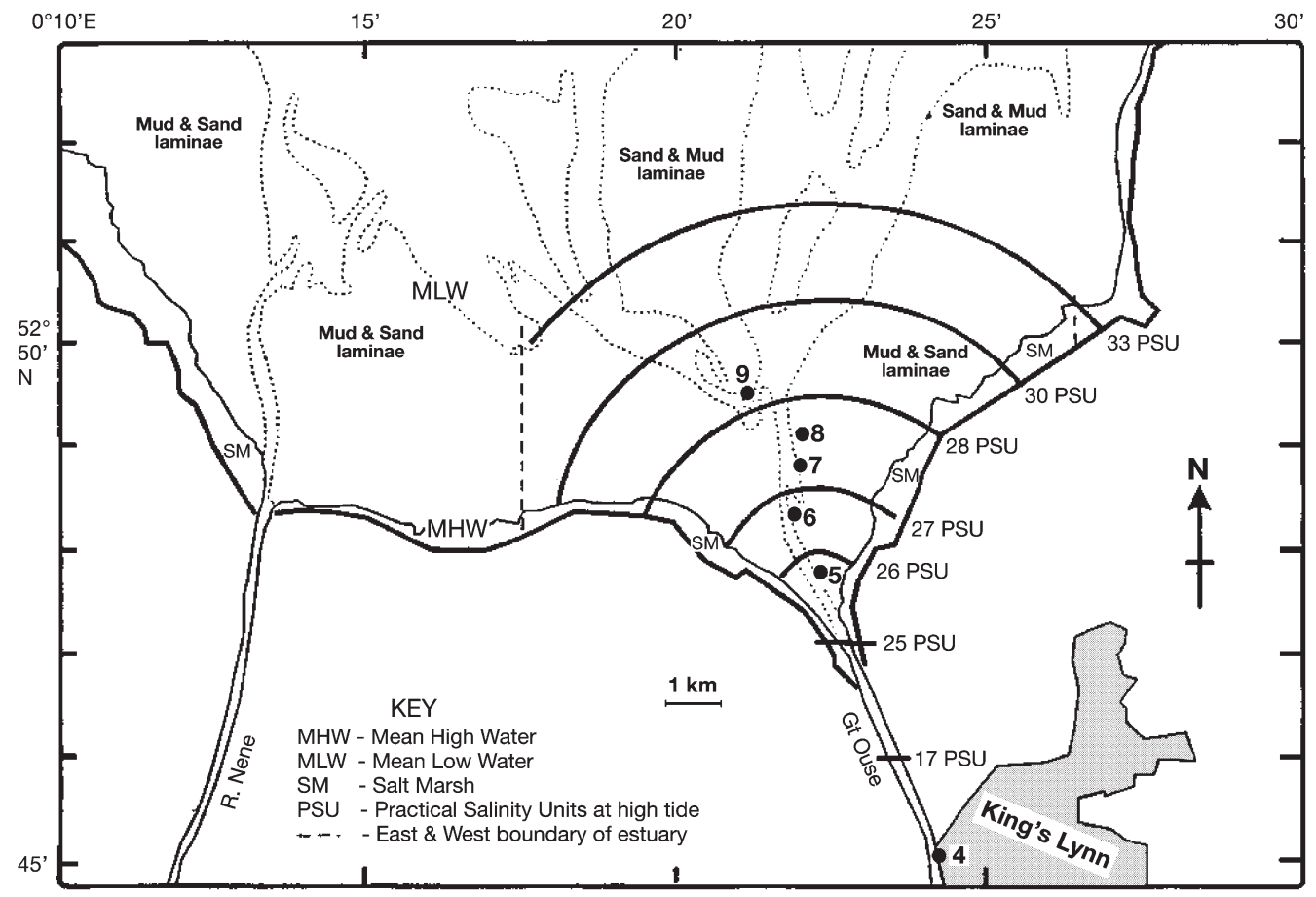

Fig. 1. Location of the 6 sites (4 to 9) in the lower Gt. Ouse (reproduced from Trimmer et al. 1998) 
Ogilvie et al. 1997a), the labile carbon:nitrate ratio (Rehr \& Klemme 1989), pH (Kim et al. 1997) nitrate concentrations (King \& Nedwell 1987) and the type of organic substrate used (Herbert 1982).

The aim of this work is to develop a diagenetic model with a more complete description of nitrate reduction by including DNRA. Data, collected as part of the JoNuS (Joint Nutrient Study) programme, from a major UK North Sea estuary (the lower Gt. Ouse, Norfolk), are used to build on an existing diagenetic model (Kelly-Gerreyn et al. 1999). The central hypothesis tested in this work is the idea that temperature is an important factor in controlling the proportioning of nitrate reduction into denitrification and DNRA in the lower Gt. Ouse sediments.

\section{OBSERVATIONAL BASIS FOR MODEL}

The lower Gt. Ouse is a temperate latitude North Sea estuary containing high concentrations of nitrate (up to $830 \mu \mathrm{M})$. A full description of the estuary and its sediment characteristics are found in Trimmer et al. (1998). Hence, only a brief description including some results is given here. Fig. 1 shows the location of the sample sites (Sites 4 to 9, Trimmer et al. 1998) visited 11 times between April 1994 and April 1995. Note that Site 4 is King's Lynn in the lower Gt. Ouse, the same Site 4 referred to in Nedwell \& Trimmer (1996) and in Kelly-Gerreyn et al. (1999). Table 2 outlines the sediment characteristics for the 6 sites of interest.

All sites were visited at low tide and remained submerged at all times. Sediment water nutrient exchange and oxygen uptake (core incubations), rates of denitrification fuelled by nitrate from the overlying water column, $D_{\mathrm{w}}$ (acetylene blockage technique), sediment temperature, organic content, porosity, and water column nutrients were measured for each visit to the sites. The methodology is described by Nedwell \& Trimmer (1996) and by Trimmer et al. (1998).

Sediment temperature ranged from 5 to $22^{\circ} \mathrm{C}$ over the season. These sediments were consistent sinks for nitrate (mean across all sites: $310 \mu \mathrm{mol} \mathrm{m} \mathrm{m}^{-2} \mathrm{~h}^{-1}$ ) and consistent sources of ammonium (mean across all sites: $270 \mu \mathrm{mol} \mathrm{m} \mathrm{m}^{-2} \mathrm{~h}^{-1}$ ). Benthic oxygen demand was significantly correlated $(\mathrm{p}<0.05)$ with temperature. $D_{\mathrm{w}}$ rates varied between 4 and $228 \mu$ molN m ${ }^{-2} \mathrm{~h}^{-1}$ across the sites and accounted for less than half (46\%) of the annual flux of nitrate to the sediment. Nitrate reduction (DNRA plus denitrification) accounted for up to 5 and $25 \%$ of the total annual organic carbon mineralisation respectively. The remainder of the carbon oxidation was assumed to be mediated by oxygen and sulphate.

\section{MODEL DESCRIPTION, EQUATIONS AND ASSUMPTIONS}

A detailed description of the basic model is given in Kelly-Gerreyn et al. (1999). Briefly, this is a one-G (Berner 1980) type reaction-diffusion model which describes the sediment column as a $1 \mathrm{D}$ vertical system of 150 equally sized adjoining boxes totalling a depth of $15 \mathrm{~cm}$. The model variables, $\mathrm{O}_{2}, \mathrm{NO}_{3}{ }^{-}, \mathrm{NH}_{4}{ }^{+}, \mathrm{SO}_{4}{ }^{2-}$, and $\mathrm{S}^{2-}$ are calculated from data-imposed steady state concentrations of total organic carbon (TOC) which is assumed to be evenly distributed in the sediment as in Kelly-Gerreyn et al. (1999). All model assumptions are the same as those in Kelly-Gerreyn et al. (1999). The model processes are nitrification, sulphide reoxidation and carbon respiration via oxygen, nitrate and sulphate. Organic carbon mineralisation produces ammonium, sulphate reduction produces free sulphide, and nitrate reduction produces $\mathrm{N}_{2}$ gas.

Nitrate reduction has been extended (see below) to account for DNRA and is the main subject of this paper. Model equations are similar to those in Table 2 of Kelly-Gerreyn et al. (1999) but have been modified to take in to account temperature changes. To do this an Arrhenius-type temperature function of the form

$$
Q_{10} \text { fact }=\mathrm{e}^{0.07(\text { Temperature-20) }}
$$

multiplies each reaction term of each model equation (see Table 2 in Kelly-Gerreyn et al. 1999). This temperature effect assumes a $Q_{10}$ of 2 .

Table 2. Sediment characteristics of the 6 sites in the lower Gt. Ouse (taken from Trimmer et al. 1998). FS = fine sand $(250-125 \mu \mathrm{m}) ; \mathrm{VFS}=$ very fine sand $(125-63 \mu \mathrm{m}) ; \mathrm{S} / \mathrm{C}=$ sand/clay $(<63 \mu \mathrm{m})$. Values are mean $\pm \mathrm{SE}$

\begin{tabular}{|lccccrr|}
\hline Site & $\begin{array}{c}\text { Particle size } \\
(>50 \% \text { w/w })\end{array}$ & $\begin{array}{c}\text { Water } \\
\text { content }\end{array}$ & $\begin{array}{c}\text { Porosity } \\
\left(\mathrm{cm}^{3} \mathrm{H}_{2} \mathrm{O} \mathrm{cm}^{-3} \text { sed. }\right)\end{array}$ & $\begin{array}{c}\text { Organic C } \\
(\% \text { dry wt })\end{array}$ & $\begin{array}{r}\text { Total N } \\
(\% \text { dry wt })\end{array}$ & $\begin{array}{c}\text { C:N ratio } \\
(\mathrm{mol}: \mathrm{mol})\end{array}$ \\
\hline 4 & VFS & $0.23 \pm 0.01$ & $0.38 \pm 0.01$ & $0.10 \pm 0.01$ & $0.02 \pm 0.01$ \\
5 & S/C & $0.33 \pm 0.03$ & $0.57 \pm 0.03$ & $0.78 \pm 0.23$ & $0.07 \pm 0.02$ & 13 \\
6 & VFS & $0.21 \pm 0.01$ & $0.38 \pm 0.01$ & $0.21 \pm 0.03$ & $0.02 \pm 0.00$ & 17 \\
7 & S/C & $0.44 \pm 0.03$ & $0.61 \pm 0.02$ & $2.23 \pm 0.35$ & $0.14 \pm 0.02$ & 19 \\
8 & S/C & $0.26 \pm 0.02$ & $0.45 \pm 0.03$ & $0.44 \pm 0.17$ & $0.03 \pm 0.01$ & 18 \\
9 & FS & $0.39 \pm 0.09$ & $0.56 \pm 0.02$ & $0.36 \pm 0.08$ & $0.06 \pm 0.02$ \\
\hline
\end{tabular}




\section{BOUNDARY CONDITIONS, INITIALISATION AND IMPOSED DATA}

In the absence of porewater data, a zero flux bottom boundary condition is imposed for all model variables (note the difference for ammonium in the upper Gt. Ouse sediments where the bottom boundary condition was fixed by measurements, see Table 4 of KellyGerreyn et al. 1999). This assumes that all reactive organic carbon has been respired at the depth of the model domain. Top boundary values at the sedimentwater interface (SWI) for oxygen, nitrate and ammonium are the mean (triplicates) core incubation concentrations in the water column during the incubation period. For all model runs, free sulphide levels are set to zero in the water column. Sulphate concentrations in the water column are calculated from salinity assuming conservative mixing from an end-member concentration of $28.23 \mathrm{mM} \mathrm{SO}_{4}{ }^{2-}$ (Wilson 1975) at 35 salinity. At Sites 5 to 9 the salinity range of 25 to 29 yields sulphate concentrations of 20.17 to $23.39 \mathrm{mM} \mathrm{SO}_{4}{ }^{2-}$, respectively. As the model is insensitive to this range in sulphate concentrations a mean sulphate concentration of $21.78 \mathrm{mM} \mathrm{SO}_{4}{ }^{2-}$ is used as the top boundary condition at Sites 5 to 9 . At low tide, salinity at Site 4 was always approximately 1 . Consequently, the sulphate top boundary concentration is calculated as $0.81 \mathrm{mM}$ at Site 4. Measured TOC concentrations (see Table 2) are imposed in each model box and assumed to be evenly distributed with depth. No porewater measurements were made in these sediments and so initial concentrations of each model variable $\mathrm{O}_{2}, \mathrm{NO}_{3}{ }^{-}, \mathrm{NH}_{4}{ }^{+}, \mathrm{SO}_{4}{ }^{2-}$ and $\mathrm{S}^{2-}$ ) are set to the same value in each model box (i.e. uniform concentrations with depth). Preliminary runs (not shown) show that the model outcome was not sensitive to the initial conditions of these solutes.

\section{TEMPERATURE AND PROPORTIONING OF NITRATE REDUCTION INTO DENITRIFICATION AND DNRA}

For the purposes of the analysis that follows, nitrate reduction, denitrification and DNRA refer to the components of these processes which are fuelled by nitrate from the overlying water column. Consequently, to avoid confusion, the terms $\mathrm{NR}_{\mathrm{w}}$ (nitrate reduction fuelled by nitrate from the overlying water), $D_{\mathrm{w}}$ and $\mathrm{DNRA}_{\mathrm{w}}$ will be used from here on. All other references to nitrate reduction, denitrification and DNRA are for total rates (i.e. the sum of rates fuelled by nitrification and by incoming nitrate from the overlying water column). Hence, it is assumed that the flux of nitrate to the sediment is equivalent to the rate of $\mathrm{NR}_{\mathrm{w}}$, where $\mathrm{NR}_{\mathrm{w}}=D_{\mathrm{w}}+\mathrm{DNRA}_{\mathrm{w}}$. This assumption is justified by the findings (Trimmer et al. 1998) that at all sites, the nitrate fluxes $(90 \%$ of which were directed into the sediment) were significantly correlated $(\mathrm{p}<0.05)$ with both the rates of $D_{\mathrm{w}}$ and the ammonium effluxes $(\mathrm{r}=$ $0.47)$, the strongest correlation being at Site $7(\mathrm{r}=0.78)$. This suggests a strong link between the nitrate flux and both $D_{\mathrm{w}}$ and $\mathrm{DNRA}_{\mathrm{w}}$ and supports the opening statements and assumptions of this section. Rates of nitrification can therefore be assumed to be negligible or in constant proportion with nitrate reduction. Furthermore, as nitrification is inhibited by the acetylene blockage technique used here, the effect of nitrification on the following calculations is, at best, minimal.

Linking the measurement of $D_{\mathrm{w}}$ with the contemporaneously measured nitrate flux enables a description of the partitioning of $\mathrm{NR}_{\mathrm{w}}$ into $\mathrm{DNRA}_{\mathrm{w}}$ and $D_{\mathrm{w}}$. Dividing $D_{\mathrm{w}}$ by the nitrate flux gives the proportion $\left(P_{\mathrm{D}}\right)$ of $\mathrm{NR}_{\mathrm{W}}$ due to $D_{\mathrm{w}}$. It follows that the remaining proportion $\left(P_{\mathrm{DNRA}}\right)$ is due to $\mathrm{DNRA}_{\mathrm{w}}$. Thus,

$$
P_{\mathrm{D}}=D_{\mathrm{w}} / \text { nitrate flux to the sediment }
$$

and

$$
P_{\mathrm{DNRA}}=1-P_{\mathrm{D}}
$$

Note that this calculation is valid only if the flux of nitrate is directed towards the sediment. As mentioned above, the lower Gt. Ouse sediments, with few exceptions (only $10 \%$ of the 112 measurements of nitrate fluxes were directed from the sediment to the water column), were consistent sinks for nitrate. The range of $P_{\mathrm{D}}$ values derived in this way is between 0.04 and 0.92 when all sites are considered (see Table 3 ). This large range indicates considerable variation in the proportioning of $\mathrm{NR}_{\mathrm{w}}$ into $\mathrm{DNRA}_{\mathrm{w}}$ and $D_{\mathrm{w}}$. Fig. 2 shows the relationship between temperature and $P_{\mathrm{D}}$ at Sites 4 to 9 . Note that because of either a lack of measurement at a particular temperature and/or a flux of nitrate out of the sediment, not all sites have $P_{\mathrm{D}}$ values at every temperature.

The values of $P_{\mathrm{D}}$ show some variation between sites. However, an overall pattern in the behaviour of $P_{\mathrm{D}}$ with temperature is discernible. Statistical analysis (1-way ANOVA tests) shows that there is no significant difference $(p=0.89)$ in the means between sites, but that there is a significant difference $(p=0.04)$ between temperatures when sites are grouped together. This suggests a correlative link between temperature and the partitioning of $\mathrm{NR}_{\mathrm{w}}$ into $D_{\mathrm{w}}$ and $\mathrm{DNRA}_{\mathrm{w}}$. It also suggests that the mean effect of temperature on $\mathrm{NR}_{\mathrm{w}}$ partitioning is the same at each site. Note that the lowest mean $P_{\mathrm{D}}$ value $(0.28 \pm 0.16$ [SE]) occurs at Site 7 , which has the highest $\mathrm{C}: \mathrm{N}$ ratio (19, Table 2$)$, while the highest mean $P_{\mathrm{D}}(0.49 \pm 0.14[\mathrm{SE}])$ occurs at Site 4 , which has the lowest C:N ratio (5, Table 2). Measurements of total organic carbon and total organic nitrogen at other times in the year were not significantly 
Table 3. Rates of uncoupled denitrification $\left(D_{\mathrm{w}}\right)$, fluxes of nitrate $\left(N_{\mathrm{f}}\right)$ across the sediment water interface and values for $P_{\mathrm{D}}$ $\left(=D_{\mathrm{w}} / N_{\mathrm{f}}\right.$, see text $)$ at the 6 sites in the lower Gt. Ouse. $\left(\mathrm{cnp}=\right.$ calculation not possible; $\mathrm{nm}=$ not measured; units $=\mu \mathrm{molN} \mathrm{m}^{-2} \mathrm{~h}^{-1}$; negative value $=$ flux to sediment)

\begin{tabular}{|c|c|c|c|c|c|c|c|c|c|c|c|c|c|c|c|c|c|c|c|}
\hline \multirow{2}{*}{$\begin{array}{l}\text { Temp. } \\
\left({ }^{\circ} \mathrm{C}\right)\end{array}$} & \multirow{2}{*}{ Month } & \multicolumn{3}{|c|}{ Site 4} & \multicolumn{3}{|c|}{ Site 5} & \multicolumn{3}{|c|}{ Site 6} & \multicolumn{3}{|c|}{ Site 7} & \multicolumn{3}{|c|}{ Site 8} & \multicolumn{3}{|c|}{ Site 9} \\
\hline & & $N_{\mathrm{f}}$ & $D_{\mathrm{w}}$ & $P_{\mathrm{D}}$ & $N_{\mathrm{f}}$ & $D_{\mathrm{w}}$ & $P_{\mathrm{D}}$ & $N_{\mathrm{f}}$ & $D_{\mathrm{w}}$ & $P_{\mathrm{D}}$ & $N_{\mathrm{f}}$ & $D_{\mathrm{w}}$ & $P_{\mathrm{D}}$ & $N_{\mathrm{f}}$ & $D_{\mathrm{w}}$ & $P_{\mathrm{D}}$ & $N_{\mathrm{f}}$ & $D_{\mathrm{w}}$ & $P_{\mathrm{D}}$ \\
\hline 5 & Jan 95 & 432.95 & 21 & cnp & $\mathrm{nm}$ & $\mathrm{nm}$ & cnp & $\mathrm{nm}$ & $\mathrm{nm}$ & cnp & -227.24 & 30 & 0.13 & $\mathrm{~nm}$ & $\mathrm{~nm}$ & cnp & -115.65 & 9 & 0.08 \\
\hline 7 & Apr 94 & -154.61 & 18 & 0.12 & -8.55 & 475 & 5.50 & 161.20 & 42 & cnp & -1149.58 & 50 & 0.04 & -1081.12 & 291 & 0.08 & -27.75 & 15 & 0.54 \\
\hline 9 & Nov 94 & -251.08 & 81 & 0.32 & -399.37 & 60 & 0.15 & 575.00 & 19 & cnp & -1070.64 & 84 & 0.08 & 383.77 & 40 & cnp & -211.83 & 8 & 0.04 \\
\hline 14 & May 94 & -184.20 & 158 & 0.86 & -300.09 & 176 & 0.59 & -327.13 & 174 & 0.53 & -433.21 & 228 & 0.53 & -474.86 & 121 & 0.25 & -121.30 & 88 & 0.73 \\
\hline 17 & Aug 94 & -165.08 & 131 & 0.79 & $\mathrm{~nm}$ & $\mathrm{~nm}$ & cnp & $\mathrm{nm}$ & $\mathrm{nm}$ & cnp & -68.68 & 63 & 0.92 & -343.83 & 32 & 0.09 & $\mathrm{~nm}$ & $\mathrm{~nm}$ & cnp \\
\hline 22 & Jul 94 & -288.311 & 1060 & .37 & -149.90 166 & 61.11 & -21 & $18.41 \quad 19$ & $0.0 s$ & & -290.68 & 500 & 21 & -56.41 & 37 & 0.66 & -30.31 & 4 & 0.13 \\
\hline
\end{tabular}

different (Trimmer 1997). Consequently it is assumed that there is no correlation between $\mathrm{C}: \mathrm{N}$ ratio and nitrate reduction partitioning (see 'Discussion'). With the exception of Site 8, the overall effect of temperature on $P_{\mathrm{D}}$ is to yield highest values at temperatures between 14 and $17^{\circ} \mathrm{C}$ and lowest values at the extremes of the observed temperature $\left(5\right.$ and $\left.22^{\circ} \mathrm{C}\right)$. On the basis of the aforementioned significant correlations $(\mathrm{p}<0.05)$ between the nitrate fluxes and both the rates of $D_{\mathrm{w}}$ and the ammonium effluxes, it is assumed from hereon that this temperature relationship holds for total nitrate reduction, i.e. $D_{\mathrm{w}}+$ coupled nitrification-denitrification $\left(D_{\mathrm{n}}\right)+\mathrm{DNRA}_{\mathrm{w}}+$ coupled nitrification-DNRA (DNRA $\mathrm{n})$. Hence, the function $P_{\mathrm{D}}$ indicates that in the lower Gt. Ouse sediments, colder $\left(<14^{\circ} \mathrm{C}\right)$ and warmer $\left(>17^{\circ} \mathrm{C}\right)$ temperatures favour DNRA and moderate $\left(14\right.$ to $\left.17^{\circ} \mathrm{C}\right)$ temperatures favour denitrification. This effect is well illustrated by the variation with temperature in the mean $P_{\mathrm{D}}$ (Fig. 2). The exceptions to the general behaviour are found at Site $9\left(P_{\mathrm{D}}=0.54\right.$ at $\left.7^{\circ} \mathrm{C}\right)$ and at Site $8\left(P_{\mathrm{D}}=0.66\right.$ at $\left.22^{\circ} \mathrm{C}\right)$. These are caused by large values of $D_{\mathrm{w}}$ relative to the nitrate flux. It is not possible to explain why these exceptions exist.
To implement this behaviour into the model, it is necessary to derive a function from this data set. The function requires a form which follows the mean $P_{\mathrm{D}}$ at all sites (Fig. 2). Fitting yields a slightly right-skewed, bell-shaped curve which has the form:

$$
\text { Fit } P_{\mathrm{D}}=A \mathrm{e}^{-\left(\frac{T_{\mathrm{opt}}-T}{\sigma}\right)^{2}}
$$

where $T_{\text {opt }}$ is the optimum temperature for selection of $D_{\mathrm{w}}$ (i.e. highest $P_{\mathrm{D}}$ ), $T$ is the temperature, $\sigma$ is the standard deviation of the temperature and $A$ is a coefficient that is derived by fitting Eq. (4) to the pooled data. The mean $P_{\mathrm{D}}$ (Fig. 2) suggests $T_{\mathrm{opt}}=16^{\circ} \mathrm{C}$. Given $\sigma=6.09$, $A$ is calculated numerically with the statistical software package SYSTAT, yielding $A=0.65$. Fig. 3 shows the fit of Eq. (4) to the pooled data of calculated $P_{\mathrm{D}}$ values for all sites. The fit has the correlation $\mathrm{r}^{2}=0.42$ and closely resembles the mean $P_{\mathrm{D}}$ which is repeated in Fig. 3 for comparison purposes. Given that there is a significant difference ( $p=0.04$, see above in this section) in the mean $P_{\mathrm{D}}$ between temperatures, there is sufficient reason to have confidence in the use of Eq. (4).
Fig. 2. Relationship of $\mathrm{P}_{\mathrm{D}}$ (temperature selection in nitrate reduction, see text) with temperature at 6 sites in the lower Gt. Ouse sediments

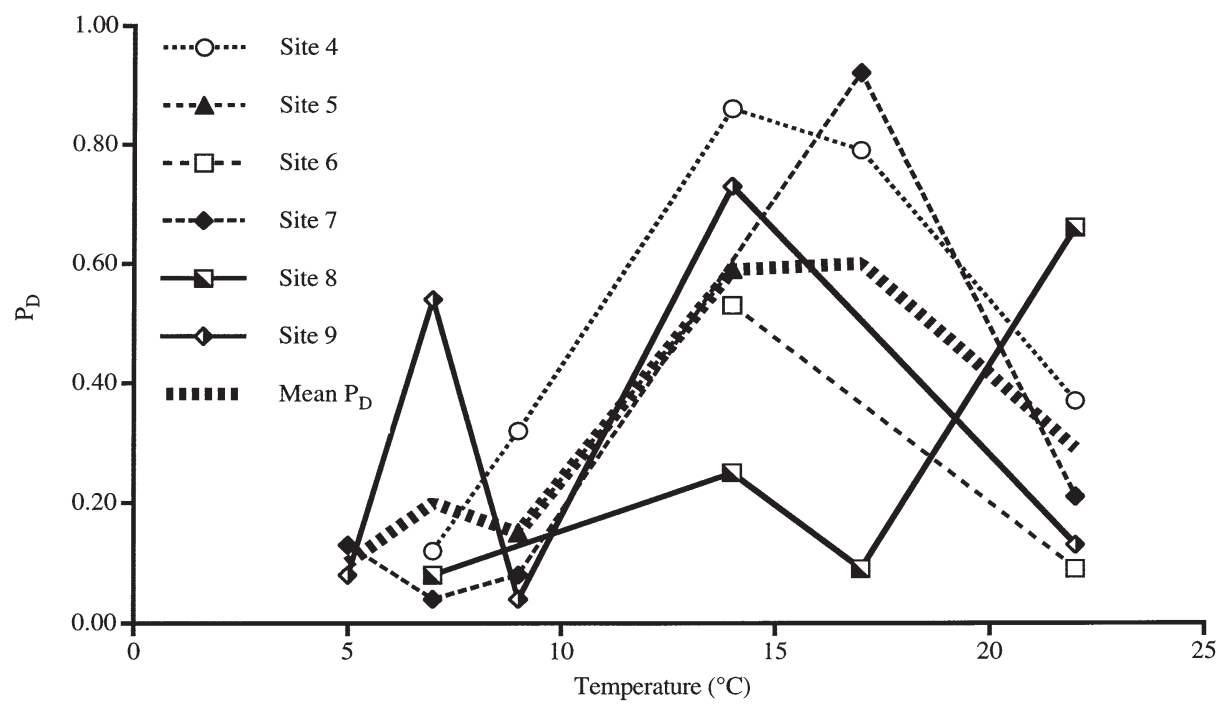




\section{IMPLEMENTATION OF EQ. (4) INTO THE MODEL}

The model equation for carbon oxidation via nitrate (SuboxMin) is

$$
\begin{aligned}
& \text { SuboxMin }= \\
& k_{\mathrm{NO}_{3}} \times[\mathrm{TOC}] \underbrace{\left(\frac{\mathrm{NO}_{3}}{\mathrm{NO}_{3}+K \mathrm{~S}_{\mathrm{NO}_{3}}}\right)}_{\mathrm{NO}_{3}{ }^{-} \text {limitation }} \underbrace{\left(1-\frac{\mathrm{O}_{2}}{\mathrm{O}_{2}+K \mathrm{~s}_{\mathrm{inhO}_{2}}}\right)}_{\mathrm{O}_{2} \text { inhibition }} \times Q_{10} \mathrm{fact}
\end{aligned}
$$

where $T$ is temperature, TOC is total organic carbon, $K_{\mathrm{NO}_{3}}$ is the half saturation constant for nitrate limitation, $\mathrm{KS}_{\mathrm{inhO}_{2}}$ is the half saturation constant for oxygen inhibition, $k_{\mathrm{NO} 3}$ is the first order rate constant and the units are in mmolC $\mathrm{m}^{-3} \mathrm{~d}^{-1}$. All parameter values used in this model (except for $k_{\mathrm{NO}_{3}}$ ) and their definitions are shown in Kelly-Gerreyn et al. (1999). Multiplying Eq. (5) by Eq. (4) yields a formula that, according to the temperature, determines what proportion of total nitrate reduction follows DNRA and denitrification. However, Eq. (5) needed modification to account for the stoichiometric conversion of TOC to either dinitrogen gas (denitrification) or to ammonium (DNRA). Using

$$
\begin{aligned}
& \left(\mathrm{CH}_{2} \mathrm{O}\right)_{106}\left(\mathrm{NH}_{3}\right)_{16}+94.4 \mathrm{HNO}_{3} \rightarrow \\
& 106 \mathrm{CO}_{2}+47.2 \mathrm{~N}_{2}+16 \mathrm{NH}_{3}+177.2 \mathrm{H}_{2} \mathrm{O}
\end{aligned}
$$

and

$$
\begin{aligned}
\left(\mathrm{CH}_{2} \mathrm{O}\right)_{106}\left(\mathrm{NH}_{3}\right)_{16}+53 \mathrm{HNO}_{3} & \rightarrow \\
106 \mathrm{CO}_{2}+69 \mathrm{NH}_{3} & +53 \mathrm{H}_{2} \mathrm{O}
\end{aligned}
$$

for denitrification and DNRA, respectively, yields stoichiometric ratios $\left(\gamma\right.$ ) of 0.4 (mole of $\mathrm{N}_{2}$ produced per mole of carbon oxidised via nitrate) and 0.65 (mole of $\mathrm{NH}_{3}$ produced per mole of carbon oxidised via nitrate and per mole of nitrate ammonified), respectively.

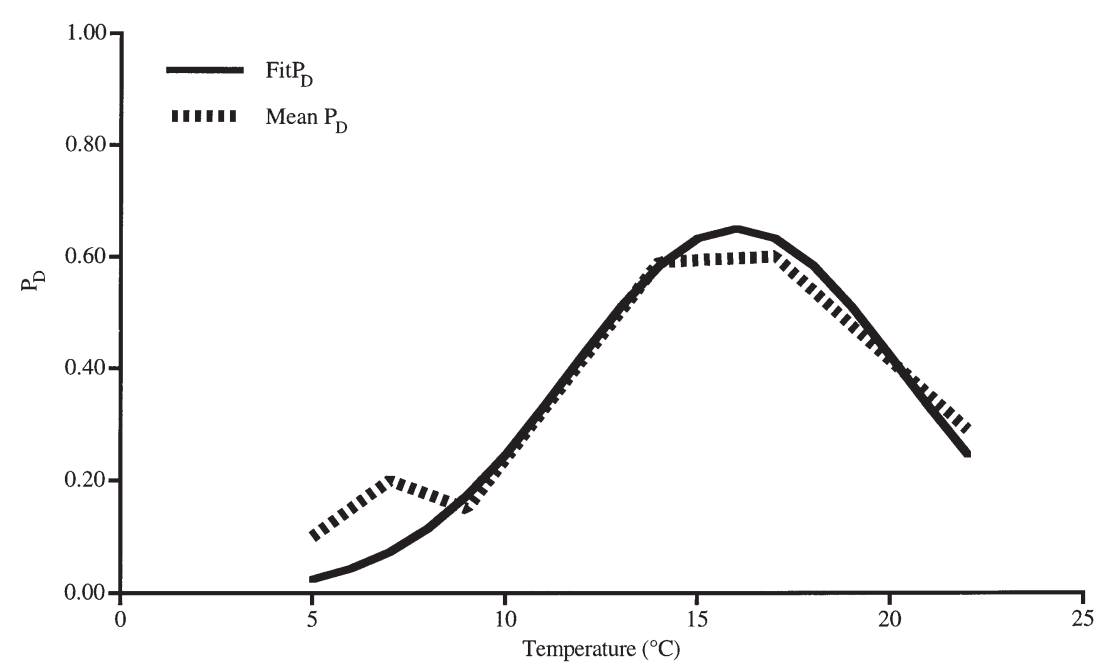

Fig. 3. Plot of Fit $P_{\mathrm{D}}$ (see text, Eq. 4) and mean $P_{\mathrm{D}}$ (from Fig. 2) versus temperature
Thus, combining Eqs (4), (5) \& (6) yields for total denitrification:

$$
\text { Fit } P_{\mathrm{D}} \times \operatorname{SuboxMin} \times \gamma_{\mathrm{N}_{2}}^{\mathrm{NO}_{3}}
$$

and combining Eqs (4), (5) \& (7) yields for total DNRA:

$$
\left(1-\text { Fit } P_{\mathrm{D}}\right) \times \text { SuboxMin } \times \gamma_{\mathrm{NH}_{4}}^{\mathrm{NO}_{3}}
$$

Note that the standard formula for nitrate reduction used in the earlier version of this model (Kelly-Gerreyn et al. 1999) and in other diagenetic models (e.g. Boudreau 1995), is an equation similar to Eq. (8) but without Fit $P_{\mathrm{D}}$.

In Eqs (8) \& (9) it must be assumed that the temperature-dependent components, Fit $P_{\mathrm{D}}$ and $Q_{10}$ fact, are mutually exclusive. In Fit $P_{\mathrm{D}}$, it is assumed that temperature is selecting different types of nitrate-reducing bacteria (King \& Nedwell 1984, Ogilvie et al. 1997a). In other words, denitrifying bacteria and nitrate ammonifiers have optimally adapted to different temperature ranges. Consequently, the effect of temperature works at the adaptive (genetic) level of the organism. In contrast, $Q_{10}$ fact works on the metabolic (enzymatic) level of the bacteria. Hence, these 2 temperature components, Fit $P_{\mathrm{D}}$ and $Q_{10}$ fact, can be considered as independent effects on nitrate reduction which justifies them being multiplied together in Eqs (8) \& (9).

Derivation of $k_{\mathrm{NO}_{3}}$ was achieved by fitting modelled rates of $D_{\mathrm{w}}$ to the peak rates of measured $D_{\mathrm{w}}$ which occurred at $14^{\circ} \mathrm{C}$ at all sites. The value of $k_{\mathrm{O}_{2}}$ and $k_{\mathrm{SO}_{4}}$ (first order rate constants for oxygen respiration and sulphate reduction, respectively) at each site is taken as the mean value (8.7 and $10 \mathrm{yr}^{-1}$, respectively) from Sites 1 to 4 in the Gt. Ouse (Table 6, Kelly-Gerreyn et al. 1999). All remaining parameter values have not been changed from their settings in Kelly-Gerreyn et al. (1999). The advantage of this is a model with only 1 parameter $\left(k_{\mathrm{NO}_{3}}\right)$ to fit, yielding a low degree of freedom.

Finally, to distinguish $D_{\mathrm{w}}$ in the model and thus facilitate comparisons with the measurements, total modelled denitrification $\left(D_{\mathrm{n}}+D_{\mathrm{w}}\right.$, Eq. 8) is multiplied by the ratio of the nitrate flux to the sediment to the sum of the nitrate flux plus the depthintegrated rate of nitrification thus:

$$
\begin{aligned}
D_{\mathrm{w}}= & \frac{\mathrm{NO}_{3}{ }^{-} \text {flux }}{\left(\mathrm{NO}_{3}{ }^{-} \text {flux }+\sum_{z=z_{\max }}^{z=z_{0}} \text { nitrification }\right)} \\
& \times \text { Fit } P_{\mathrm{D}} \times \text { SuboxMin } \times \gamma_{\mathrm{N}_{2}}^{\mathrm{NO}_{3}}
\end{aligned}
$$

where the interval $z_{0}$ to $z_{\max }$ is the total depth $(15 \mathrm{~cm})$ considered in the model. Note that although nitrification has been assumed to have a negligible effect on the 
calculation of $P_{\mathrm{D}}$ (because of the use of the acetylene blockage technique), this does not mean that nitrification is not occurring in the lower Gt. Ouse sediments. Hence, nitrification is included in the model.

\section{MODEL RUNS}

The model is run for each site and each temperature (i.e. for different months). Differences between model runs at each site are thus caused by temperature and additionally by variations in the water column boundary values for the three measured solutes $\mathrm{O}_{2}, \mathrm{NO}_{3}{ }^{-}$and $\mathrm{NH}_{4}{ }^{+}$. Differences between sites are due to differences in TOC concentrations, porosity and top boundary values. Temperature does not vary between sites. Model and measurement-derived results (i.e. $D_{\mathrm{w}}$ and $\mathrm{DNRA}_{\mathrm{w}}$ rates) are displayed with respect to temperature. The contribution of DNRA to total ammonium production is also presented. Nutrient fluxes across the SWI are only mentioned (and not displayed) for completeness, as they are not the main topic of this paper.

\section{RESULTS}

\section{Nitrate reduction}

Measured and modelled rates of sedimentary $D_{\mathrm{w}}$ are plotted in Fig. 4 against sediment temperature at the 6 sites in the lower Gt. Ouse. The general pattern in the observations shows a bell-shaped curve with rates of denitrification peaking at $14^{\circ} \mathrm{C}$ (May 1994) at all sites. Modelled rates of $D_{\mathrm{w}}$ (which use Eq. 10) show the same relationship with temperature as the observations. From here on, this model run is referred to as $\mathrm{M}+$ Fit $P_{\mathrm{D}}$. The comparison between $\mathrm{M}+\mathrm{Fit} P_{\mathrm{D}}$ and the measurements is highly significant $(p<0.001)$. For comparison purposes, model output which does not account for temperature-based proportioning of nitrate reduction (i.e. Eq. 8 without Fit $P_{\mathrm{D} i}$ henceforth this model run is called $\mathrm{M}-$ Fit $P_{\mathrm{D}}$ ) is also plotted in Fig. 4. The correlation between $\mathrm{M}-$ Fit $P_{\mathrm{D}}$ and the observations is not significant $(\mathrm{p}=0.18)$. As with $\mathrm{M}+$ Fit $P_{\mathrm{D}}, \mathrm{M}-$ Fit $P_{\mathrm{D}}$ was derived by fitting the model to rates of $D_{\mathrm{w}}$ measured at $14^{\circ} \mathrm{C}$. Fitted values for the first order rate constant $k_{\mathrm{NO}_{3}}$ derived by $\mathrm{M}+$ Fit $P_{\mathrm{D}}$ and $\mathrm{M}-$ Fit $P_{\mathrm{D}}$ are shown in Table $4 . k_{\mathrm{NO}_{3}}$ values are higher in $\mathrm{M}+$ Fit $P_{\mathrm{D}}$ by a mean factor of 2.36 compared to $\mathrm{M}-$ Fit $P_{\mathrm{D}}$.

Rates of $D_{\mathrm{w}}$ in $\mathrm{M}-\mathrm{Fit} P_{\mathrm{D}}$ overestimate the observations by a mean factor of 5.8 at temperatures $<14^{\circ} \mathrm{C}$ compared to a factor of 1.4 for $\mathrm{M}+\mathrm{Fit} P_{\mathrm{D}}$. For temperatures $>14^{\circ} \mathrm{C}, D_{\mathrm{w}}$ rates in both $\mathrm{M}-$ Fit $P_{\mathrm{D}}$ and $\mathrm{M}+$ Fit $P_{\mathrm{D}}$ are a mean factor of $\sim 2$ higher than the observations. Concentrations of nitrate in the overlying water col- umn are also plotted in Fig. 4. As expected, nitrate levels decrease with increasing temperature at all sites, reflecting weather induced seasonality (i.e. higher runoff in winter compared to summer). This in part accounts for the decrease in both model and measured $D_{\mathrm{w}}$ at temperatures $>14^{\circ} \mathrm{C}$ (see 'Discussion').

$D_{\mathrm{w}}$ rates in $\mathrm{M}+\mathrm{Fit} P_{\mathrm{D}}$ are consistently higher than the observations (mean factor $=4$ ) at $16^{\circ} \mathrm{C}$. Site 4 is the exception to this. Note that values of Fit $P_{\mathrm{D}}$ are at a maximum (0.66) at this temperature.

Fig. 5 compares modelled and calculated rates of $\mathrm{DNRA}_{\mathrm{w}}$ at all sites in the lower Gt. Ouse. Calculated rates of $\mathrm{DNRA}_{\mathrm{w}}$ were derived as the difference between the measurements of the flux of nitrate into the sediment and the rates of $D_{\mathrm{w}}$. Variability in the calculated rate was determined by adding the variances of both the nitrate fluxes and the $D_{\mathrm{w}}$ rates and then subtracting double the covariance of the 2 measurements:

$$
\begin{aligned}
\operatorname{Var}\left(\mathrm{DNRA}_{\mathrm{w}}\right)= & \operatorname{Var}\left(\mathrm{NO}_{3}^{-} \text {flux }\right)+\operatorname{Var}\left(D_{\mathrm{w}}\right)- \\
& 2 \operatorname{CoVar}\left(\mathrm{NO}_{3}^{-} \text {flux, } D_{\mathrm{w}}\right)
\end{aligned}
$$

where Var is the variance and CoVar is the covariance. This assumes that the nitrate flux and the rate of $D_{\mathrm{w}}$ are not independent of one another.

In some cases (Site 4 March 1995, at $7^{\circ} \mathrm{C}$ i November $1994,9^{\circ} \mathrm{C}$; May $1994,14^{\circ} \mathrm{C}$; and September 1994, $15.5^{\circ} \mathrm{C}$; see Fig. 5), the standard error is larger than the calculated rate of $\mathrm{DNRA}_{\mathrm{w}}$. This impossible spread in DNRA $_{w}$ is caused by the large variation in the nitrate flux (i.e. within the same sample of triplicate measurements both influxes and effluxes of nitrate were measured). However, overall, the modelled rates of $\mathrm{DNRA}_{\mathrm{w}}$ compare well with the calculated rates. Linear regression shows a significant correlation $(\mathrm{p}<$ 0.0001) between modelled and calculated $\mathrm{DNRA}_{\mathrm{w}}$. In some months (March 1995, $7^{\circ} \mathrm{C}$; November $1994,9^{\circ} \mathrm{C}$ at Site 7 ; March $1995,7^{\circ} \mathrm{C}$ at Site 8) calculated rates $\left(\sim 1000 \mu \mathrm{molN} \mathrm{m} \mathrm{m}^{-2} \mathrm{~h}^{-1}\right)$ of $\mathrm{DNRA}_{\mathrm{w}}$ are much greater than the modelled rates $\left(\sim 150\right.$ to $300 \mu$ molN m $\left.{ }^{-2} \mathrm{~h}^{-1}\right)$. Overall, the model underestimates the calculated rates of $\mathrm{DNRA}_{\mathrm{w}}$ (regression slope $=0.3$ ).

Table 4. Values of the first order rate constant for nitrate reduction used in the model output with $\left(\mathrm{M}+\mathrm{Fit} P_{\mathrm{D}}\right)$ and without (M-Fit $P_{\mathrm{D}}$ ) Eqs (8) \& (9) (units, $\mathrm{yr}^{-1}{ }^{2} \mathrm{NB}: k_{\mathrm{O}_{2}}=8.7 \mathrm{yr}^{-1}$; $k_{\mathrm{SO}_{4}}=10 \mathrm{yr}^{-1}$; these latter 2 parameters are the mean values

for the 4 sites in the Gt. Ouse, Kelly-Gerreyn et al. 1999)

\begin{tabular}{|lccc|}
\hline Site & M + Fit $P_{\mathrm{D}}$ & $\mathrm{M}-$ Fit $P_{\mathrm{D}}$ & Factor difference \\
\hline 4 & 11.57 & 4.68 & 2.47 \\
5 & 0.79 & 0.34 & 2.29 \\
6 & 4.83 & 1.90 & 2.54 \\
7 & 1.18 & 0.52 & 2.25 \\
8 & 1.45 & 0.61 & 2.36 \\
9 & 0.83 & 0.37 & 2.25 \\
\hline
\end{tabular}



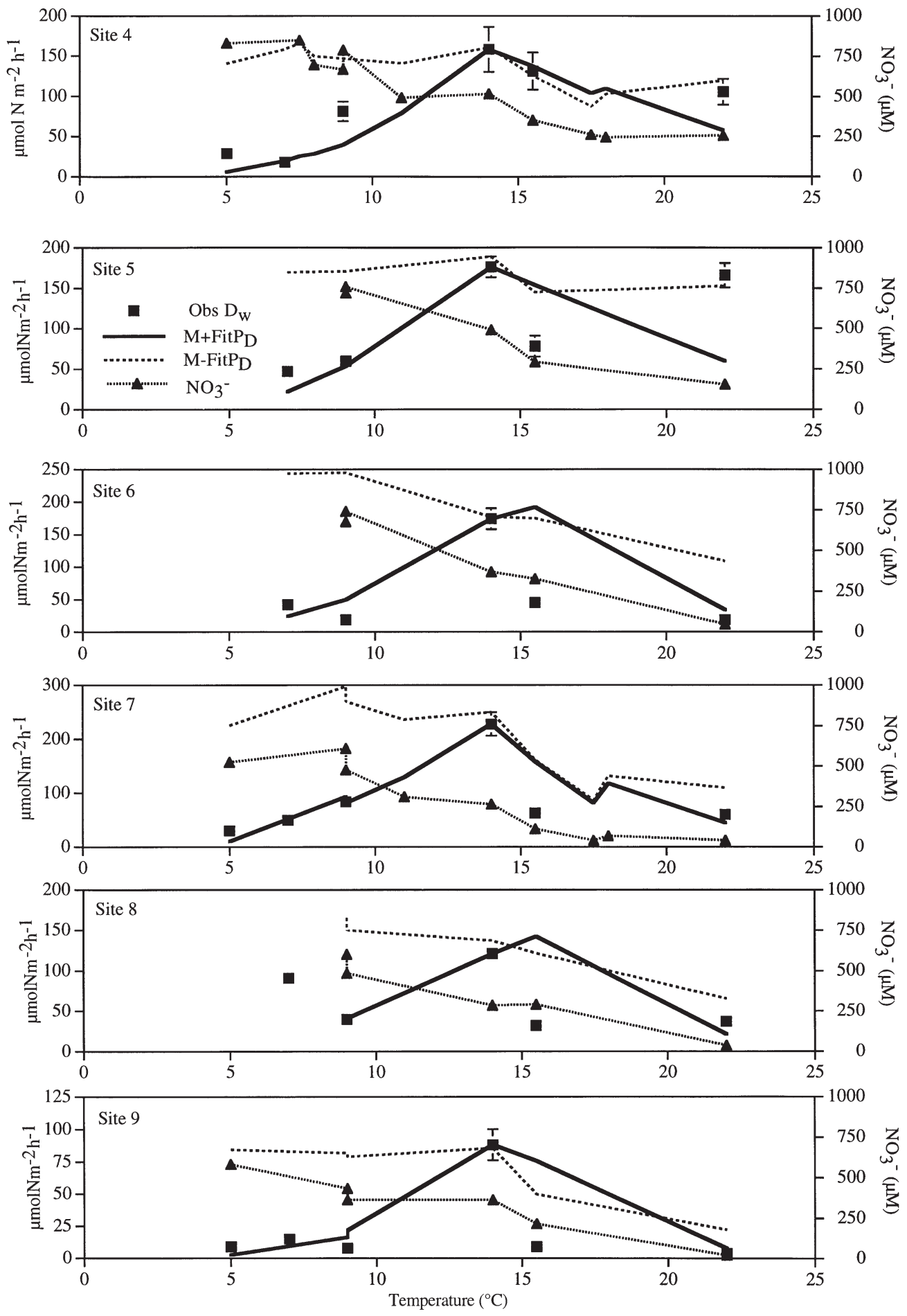

Fig. 4. Modelled (M+Fit $P_{\mathrm{D}}$ and $\mathrm{M}-\mathrm{Fit} P_{\mathrm{D}}$, see text for details) and observed rates of uncoupled denitrification $\left(D_{\mathrm{w}}\right)$ at 6 sites in the

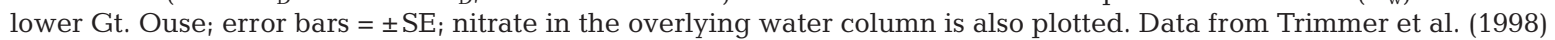

Fig. 6 shows the percentage contribution of total DNRA to total ammonium production for each temperature at all sites. (DNRA ammonium production consists of ammonium derived from both the nitrate nitrogen and from the nitrogen bound in the organic matter (see
Eq. 7). The remaining percentage is due to the respiration of TOC by oxygen reduction, denitrification and sulphate reduction. Site 4 has the highest percentage contribution of DNRA to the total production of ammonium $(15$ to $58 \%$, mean $=36 \%)$, then, in descending order of 

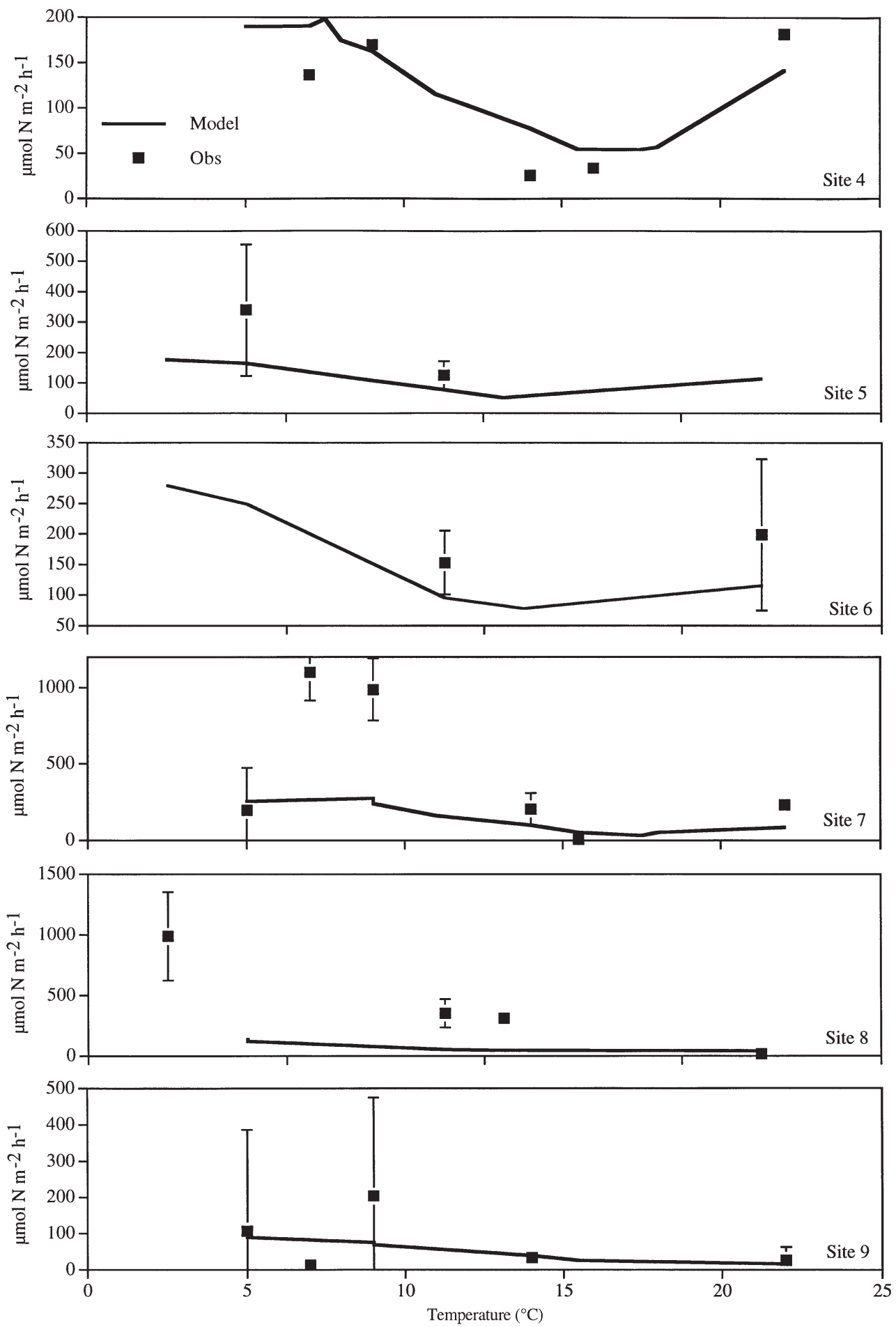

Fig. 5. Modelled and calculated rates of sedimentary DNRA $\mathrm{w}_{\mathrm{w}}$ (see text for details) at 6 sites in the lower Gt. Ouse. Calculated rates $=$ measured nitrate flux to sediment - measured rate of denitrification $\left(D_{\mathrm{w}}\right)$; error bars $= \pm \mathrm{SE}$. Data from Trimmer et al. 1998)

contribution, Site 6 ( 7 to $47 \%$, mean $=24 \%$ ), Site 8 ( 4 to $31 \%$, mean $=17 \%)$, Site $7(2$ to $37 \%$, mean $=16 \%$ ), Site 5 $(5$ to $31 \%$, mean $=16 \%)$ and Site $9(1$ to $16 \%$, mean = $7 \%$ ). Each site shows a similar pattern: decreasing percentage contributions to the ammonium pool from total
DNRA with increasing temperatures. Sites 5 and 7 show a slight increase (by $2 \%$ ) in the percentage contribution between 15.5 and $22^{\circ} \mathrm{C}$ and between 18 and $22^{\circ} \mathrm{C}$, respectively. Site 4 percentage contributions increase by a greater amount, from 15 to $28 \%$, between 18 and $22^{\circ} \mathrm{C}$. 


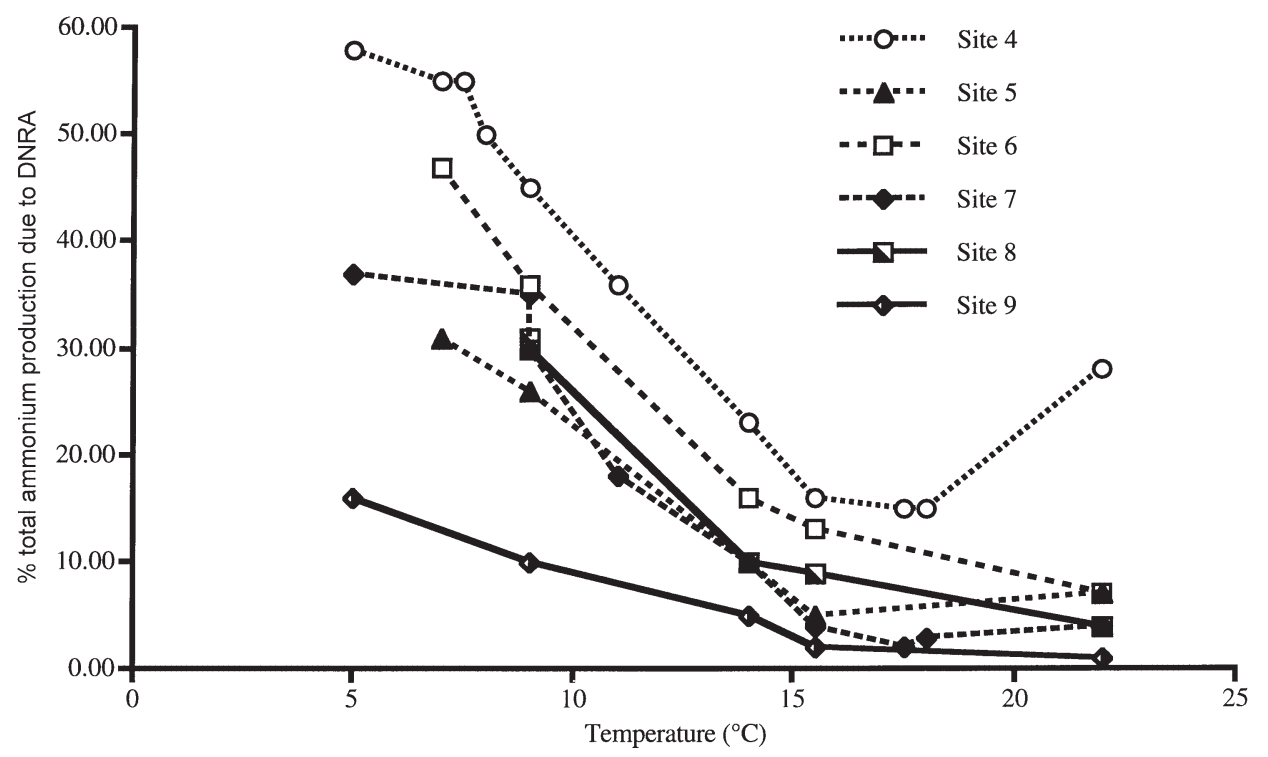

Fig. 6. Percentage contribution of DNRA to total ammonium production at each temperature at 6 sites in the lower Gt. Ouse. The remaining percentage is due to TOC mineralisation

For a complete report of the performance of the model, the nutrient $\left(\mathrm{NO}_{3}{ }^{-}\right.$and $\left.\mathrm{NH}_{4}{ }^{+}\right)$exchange output (not displayed) from the model is significantly ( $\mathrm{p}<$ $0.05)$ correlated $\left(r^{2}=0.63\right.$ and $r^{2}=0.71$, respectively) with the observed data. Similarly, modelled oxygen fluxes are significantly $(p<0.05)$ correlated $\left(r^{2}=0.66\right)$ with the measurements. This aspect of the model is not discussed further.

\section{DISCUSSION}

The range of values of Fit $P_{\mathrm{D}}(0.07$ to 0.66$)$ suggests that $\mathrm{NR}_{\mathrm{w}}$ (and by assumption, total nitrate reduction) in the lower Gt. Ouse sediments is always made up of contributions from both DNRA and denitrification. One

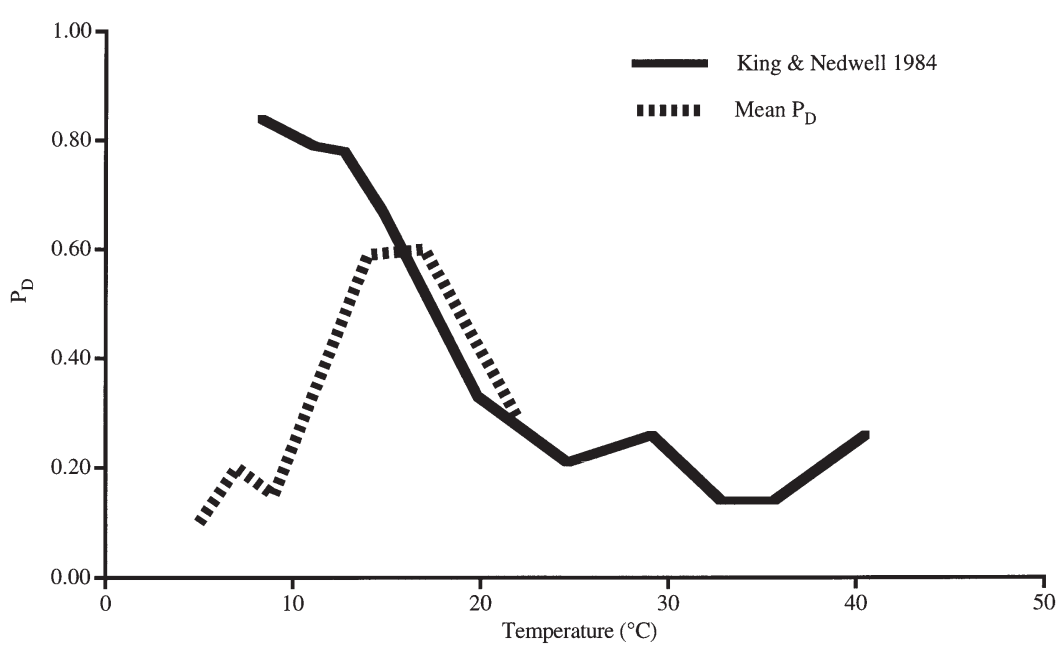

Fig. 7. Comparison of Fit $P_{\mathrm{D}}$ and data from King \& Nedwell (1984) versus temperature. (King \& Nedwell data calculated from their Fig. 4) process never fully dominates the other, suggesting considerable overlap of denitrifying and nitrate ammonifying activity.

The $P_{\mathrm{D}}$ values also show that $\mathrm{DNRA}_{\mathrm{w}}$ (and by assumption, total DNRA) is the more significant process. This is in line with many coastal studies of nitrate reduction from different parts of the world (Table 1). For a number of east coast UK estuaries, Herbert \& Nedwell (1990) showed that fermentative bacteria were numerically dominant and potentially the most active nitrate reducing bacteria in the sediments. Similar bacterial findings have been reported for a wide range of sediment types in the northwest European shelf region (Cole \& Brown 1980).

According to the temperature relationship derived from this data (Fit $P_{\mathrm{D}}$ Eq. 4 ) both $D_{\mathrm{w}}$ and $\mathrm{DNRA}_{\mathrm{w}}$ occur to varying degrees, at all temperatures. However, both colder $\left(<14^{\circ} \mathrm{C}\right)$ and warmer $\left(>17^{\circ} \mathrm{C}\right.$ ) temperatures favour $\mathrm{DNRA}_{\mathrm{w}}$ over $D_{\mathrm{w}}$ while $D_{\mathrm{w}}$ is the favoured pathway in $\mathrm{NR}_{\mathrm{w}}$ at moderate temperatures $\left(14\right.$ to $\left.17^{\circ} \mathrm{C}\right)$. Given the significant correlations $(p<0.05)$ between nitrate fluxes and ammonium effluxes in these sediments, it is likely that this temperature effect is also true for total nitrate reduction.

The relationship of $P_{\mathrm{D}}$ to temperature may be explained by observations which suggest that nitrate ammonifying bacteria and denitrifiers are adapted to different temperatures (King \& Nedwell 1984, Ogilvie et al. 1997a). However, plotting the King \& Nedwell (1984) results alongside Fit $P_{\mathrm{D}}$ (Fig. 7) shows differences in the relationship between the proportioning of nitrate reduction and temperature. 
Using anoxic estuarine sediment slurries and chemostat experiments, King \& Nedwell (1984) show that colder temperatures favour denitrification while warmer temperatures are preferred by nitrate-ammonifying bacteria, leading to the idea that denitrifiers are psychrophilic and that nitrate ammonifiers are mesophilic. Their results have subsequently been supported by fieldwork (Ogilvie et al. 1997b) from the same estuary (the Colne, UK east coast, a high-nitrate, temperate estuary). These 2 quoted studies suggest that Fit $P_{\mathrm{D}}$ derived from the lower Gt. Ouse data, does not reflect a causal relationship between sediment temperature and the pathway selected in nitrate reduction. The 'cold' response of $\mathrm{NR}_{\mathrm{w}}$ favouring $\mathrm{DNRA}_{\mathrm{w}}$ may be an artefact of Fit $P_{\mathrm{D}}$. That is, the assumption that the nitrate flux to the sediment is equivalent to dissimilatory $\mathrm{NR}_{\mathrm{w}}$ may not be true. This is difficult to check without measurements of DNRA and this assumption has been warned against in previous studies (Jørgensen 1989). However, this warning is concerned with sediment populated by either heterotrophic bacteria, which carry out assimilatory nitrate reduction to meet nutritional requirements, and/or benthic algae. Assimilatory nitrate reduction is known to be inhibited in the presence of ammonium (Cole \& Brown 1980) and can therefore be ignored in this data. It has already been mentioned that the effects of benthic algae were removed by dark incubations. Although it has been shown that nutrient assimilation can continue after the onset of darkness (Rysgaard et al. 1993), seasonal measurements of both light and dark nutrient exchange and of chlorophyll a (consistently $<3 \mu \mathrm{g} \mathrm{g}{ }^{-1}$ dry sediment) showed that light had no significant effect on the nutrient flux (Trimmer et al. 1998). In contrast to the latter, where chlorophyll concentrations are much higher (e.g. > $26 \mu g^{-1}$ dry sediment; Dong et al. 2000), it has been shown that light makes a significant difference to nutrient fluxes compared to dark incubations.

The preferred selection for $\mathrm{DNRA}_{\mathrm{w}}$ at the colder temperature range indicated by Fit $P_{\mathrm{D}}$ is caused by the high winter nitrate fluxes relative to the low rates of $D_{\mathrm{w}}$. The latter are likely to be caused by cold temperatures slowing down bacterial metabolic activity. A major cause of high solute fluxes can be the activity of macrofauna (Aller \& Aller 1998). However, the lack of benthic animals (a consistent finding during a total of $4 \mathrm{yr}$ of study in which hundreds of cores were sifted; Trimmer 1997) in the lower Gt. Ouse sediments excludes this factor. Diffusive enhancement by turbulence across the SWI may cause increased solute fluxes (Lohse et al. 1996) but the core incubations used to derive the data in Trimmer et al. (1998) removes this effect. It is concluded that the high nitrate fluxes observed in the colder months (e.g. Site 7, November 1994, March 1995, temperature $=9$ and $7^{\circ} \mathrm{C}$ respec- tively, Table 3) is due to high nitrate-ammonifying activity.

Alternative explanations for the dominance of $\mathrm{DNRA}_{\mathrm{w}}$ in summer may be due to the fact that (i) sediments become increasingly reduced environments (Jørgensen 1989) or that (ii) labile carbon to nitrate ratios (Herbert \& Nedwell 1990) are high relative to those in winter. These factors cannot be excluded from this work and it is likely that the dominance of DNRA in summer is caused by a combination of temperature, labile carbon:nitrate ratios and $\mathrm{pH}$. However, the temperature relationship with $\mathrm{NR}_{\mathrm{w}}$ (Fig. 3) suggests an important controlling effect. This implies that in the lower Gt. Ouse sediments, nitrate-ammonifying bacteria are best adapted to both colder and warmer temperatures, while denitrifiers only outcompete them over a small intermediate temperature range. This runs counter to the findings from laboratory based work (King \& Nedwell 1987, Herbert \& Nedwell 1990) which show that high nitrate concentrations (as found in winter) favour denitrification. However, plotting Fit $P_{\mathrm{D}}$ against overlying nitrate concentrations in the lower Gt. Ouse (not shown) shows no relationship between high nitrate concentrations (shown to be proportional to the nitrate concentration in the top $1 \mathrm{~cm}$ of sediment in the Gt. Ouse sediments; Nedwell \& Trimmer 1996) and Fit $P_{\mathrm{D}}$. Consequently, for the lower Gt. Ouse sediments, it is proposed that temperature is a dominant controlling factor in determining the end products (N-gases or ammonium) of total nitrate reduction.

It is possible that the temperature range favouring denitrification is wider than is suggested by the calculations of $P_{\mathrm{D}}$. There is a $5^{\circ} \mathrm{C}$ gap between 9 and $14^{\circ} \mathrm{C}$ and between 17 and $22^{\circ} \mathrm{C}$ for which there is no data for $P_{\mathrm{D}}$ (Table 3). If true, seasonal denitrification may be of a longer duration compared with DNRA. However, this does not change the main conclusions of this work (see below) although the overall annual balance of the 2 nitrate competing processes may favour the production of N-gases over ammonium. Note that Trimmer et al. (1998) calculated that $46 \%$ of the nitrate flux into these sediments was converted to $\mathrm{N}$-gases, the remainder ending up as ammonium.

Attempts to model $D_{\mathrm{w}}$ in the lower Gt. Ouse sediments without partitioning nitrate reduction $\left(\mathrm{M}-\right.$ Fit $\left.P_{\mathrm{D}}\right)$ were not successful across the full range $\left(5\right.$ to $\left.22^{\circ} \mathrm{C}\right)$ of observed temperatures. Measured rates of $D_{\mathrm{w}}$ could not be reproduced by the model $\left(\mathrm{M}-\right.$ Fit $\left.P_{\mathrm{D}}\right)$ at the lower temperatures $\left(<14^{\circ} \mathrm{C}\right)$. In contrast, for temperatures $\geq 14^{\circ} \mathrm{C}$ the effect of decreasing nitrate concentrations in the overlying water column on $D_{\mathrm{w}}\left(\mathrm{M}-\right.$ Fit $\left.P_{\mathrm{D}}\right)$ was similar to that with the run of $\mathrm{M}+$ Fit $P_{\mathrm{D}}$. A test run was carried out to determine whether the decrease in $D_{\mathrm{w}}$ for temperatures $\geq 14^{\circ} \mathrm{C}$ is due to: (1) lowering 
nitrate concentrations in the water column; (2) the effects of temperature selection favouring $\mathrm{DNRA}_{\mathrm{w}_{i}}$ or (3) both (1) and (2). The test run (not shown) used $\mathrm{M}+$ Fit $P_{\mathrm{D}}$ with a constant top boundary value for nitrate (the mean across all sites was used $=406 \mu \mathrm{M}$ ) for all temperatures at all sites. As before, the model was calibrated to rates of $D_{\mathrm{w}}$ at $14^{\circ} \mathrm{C}$. Modelled $D_{\mathrm{w}}$ rates for temperatures $>14^{\circ} \mathrm{C}$ were higher than the standard run (i.e. $\mathrm{M}+$ Fit $P_{\mathrm{D}}$ with observed boundary values) by a mean factor of 2.3. This suggests that lowering nitrate concentrations are needed to better represent the observed rates of $D_{\mathrm{w}}$ in summer. Hence, both temperature selection and changing nitrate concentrations are needed in the model.

It is possible that the variability in $P_{\mathrm{D}}$ may be caused by the variable efficiency of the acetylene blockage technique (Seitzinger et al. 1993). However, these latter authors added acetylene to only the overlying water to measure sediment denitrification. In the denitrification data collected by Trimmer et al. (1998), acetylene was injected into the sediments and in this way the method has been shown to give reliable estimates (Koike \& Sørensen 1988, Knowles 1990, van Raaphorst et al. 1992) as argued by Ogilvie et al. (1997b). Furthermore, rates of $D_{\mathrm{w}}$ are well correlated $(r=0.83)$ with seasonal variations in overlying nitrate concentrations (Trimmer et al. 1998) which has been shown in other studies (Ogilvie et al. 1997b, Dong et al. 2000).

Nitrification is inhibited by the acetylene blockage technique and consequently has little effect on the calculation of $P_{\mathrm{D}}$. This does not mean that nitrification is absent in these sediments. Only $10 \%$ of the nitrate fluxes are directed out of the sediment (Table 3) indicating, in these situations, that nitrification is greater than total nitrate reduction. However, the large majority $(90 \%)$ of the measured nitrate fluxes are directed into the sediment (Table 3) and more importantly, they are significantly $(\mathrm{p}<0.05)$ correlated to both rates of $D_{\mathrm{w}}$ and ammonium effluxes. This suggests that total nitrate reduction, not just $\mathrm{NR}_{\mathrm{w}}$, is correlated to the nitrate flux which supports the assumption that the relationship between $P_{\mathrm{D}}$ and temperature can be extended to total nitrate reduction in these sediments. Consequently, for these sediments, nitrification is (1) negligible and invariant with temperature or (2) in constant proportion to nitrate reduction.

The percentage contribution of total DNRA to total ammonium production in the lower Gt. Ouse sediments (Fig. 6) varies between 1 and 58\% across all temperatures and sites. This is a large variation fuelled by the range (21 to $830 \mathrm{\mu M} \mathrm{NO}_{3}^{-}$) in overlying nitrate concentrations since most ( $>70 \%$ for all sites) of the ammonium nitrogen produced by DNRA derives from the nitrate nitrogen rather than the nitrogen bound in the organic matter. This is not surprising given the stoichiometry of Eq. (7) which yields $1 \mathrm{~mol}$ of ammonium for every mole of nitrate reduced and 0.15 (16/106) mol of ammonium for every mole of TOC mineralised via nitrate. Consequently, variations in concentrations of nitrate in the water column have a considerable effect on the production of ammonium from DNRA. This helps to explain the significant $(\mathrm{p}<0.05)$ correlations found between the measured nitrate fluxes and the ammonium effluxes in the lower Gt. Ouse sediments (Trimmer et al. 1998). The increase in the percentage of ammonium production from DNRA at Sites 4, 5 and 7 (Fig. 6) is caused by increases in the nitrate concentration in the overlying water between 15.5 and $22^{\circ} \mathrm{C}$. This effect also explains the increases in modelled DNRA $_{\mathrm{w}}$ rates at the same sites and temperatures (Fig. 5).

The differences between the sites (Fig. 6) are related to differences in both the first order rate constant $\left(k_{\mathrm{NO}_{3}}\right)$ for nitrate reduction (Table 4 ) and the nitrate concentrations in the overlying water (Fig. 4). A comparison between the mean percentage contribution of DNRA to total ammonium production at each site with both the mean nitrate concentration in the water column and the $k_{\mathrm{NO}_{3}}$ value at each site is shown in Table 5. High $k_{\mathrm{NO}_{3}}$ values coincide with high percentage contributions of DNRA to total ammonium production (Sites 4, 6, 7 and 8). The order of the percentage contribution of DNRA to ammonium production in the last 2 sites in Table 5 does not match the order of the $k_{\mathrm{NO}_{3}}$ values. This is because the mean nitrate concentration is greater at Site 5 $\left(484 \mu \mathrm{M} \mathrm{NO}_{3}{ }^{-}\right)$than at Site $9\left(330 \mu \mathrm{M} \mathrm{NO}_{3}{ }^{-}\right)$even though the 2 sites have similar $k_{\mathrm{NO}_{3}}$ values $(0.79$ and $0.83 \mathrm{yr}^{-1}$, respectively). A similar argument explains why Sites 5 and 7 have the same percentage: the higher $k_{\mathrm{NO}_{3}}$ value by a factor of 1.49 at Site 7 compared to Site 5 compensates for the lower mean nitrate concentration at Site 7 compared to Site 5 .

The range of fitted values of the first order rate constants, $k_{\mathrm{NO}_{3}}$, for nitrate reduction $\left(0.79\right.$ to $11.57 \mathrm{yr}^{-1}$, Table 4) falls within the published range of first order rate constants for TOC degradation (e.g. 0.1 to $4.8 \mathrm{yr}^{-1}$,

Table 5. Comparison of the mean percentage contribution of DNRA to total ammonium production ( $\%$ DNRA $\left.\Rightarrow \mathrm{NH}_{4}{ }^{+}\right)$with both $k_{\mathrm{NO}_{3}}$ values and the mean nitrate concentration in the water column at 6 sites in the lower Gt. Ouse

\begin{tabular}{|lrrr|}
\hline Site & \% DNRA $\Rightarrow \mathrm{NH}_{4}{ }^{+}$ & $\begin{array}{r}k_{\mathrm{NO}_{3}} \\
\left(\mathrm{yr}^{-1}\right)\end{array}$ & $\begin{array}{c}\mathrm{NO}_{3}^{-} \\
(\mu \mathrm{M})\end{array}$ \\
\hline 4 & 36 & 11.57 & 540 \\
5 & 16 & 0.79 & 484 \\
6 & 24 & 4.83 & 432 \\
7 & 16 & 1.18 & 271 \\
8 & 17 & 1.45 & 340 \\
9 & 7 & 0.83 & 330 \\
\hline
\end{tabular}


McNichol et al. $1988 ; 0.005$ to $53 \mathrm{yr}^{-1}$, Andersen 1996; $0.2-7 \mathrm{yr}^{-1}$, Middelburg et al. 1996). The larger values in model run $\mathrm{M}+$ Fit $P_{\mathrm{D}}$ compared to $\mathrm{M}-\mathrm{Fit} P_{\mathrm{D}}$ (Table 4) are caused by the presence of Fit $P_{\mathrm{D}}$. That is, only a fraction of the nitrate reduction in $\mathrm{M}+\mathrm{Fit} P_{\mathrm{D}}$ can follow the denitrification pathway, compared to $100 \%$ in $\mathrm{M}-\mathrm{Fit} P_{\mathrm{D}}$. Thus, higher $k_{\mathrm{NO} 3}$ values are needed in $\mathrm{M}+\mathrm{Fit} P_{\mathrm{D}}$ to fit rates of denitrification to the observed rates at $14^{\circ} \mathrm{C}$.

\section{CONCLUSIONS}

In the lower Gt. Ouse sediments, temperature selection in dissimilatory $\mathrm{NR}_{\mathrm{w}}$ can be used to model both $D_{\mathrm{w}}$ and $\mathrm{DNRA}_{\mathrm{w}}$. It is assumed from the significant correlations $(\mathrm{p}<0.05)$ between nitrate fluxes and both the rates of $D_{\mathrm{w}}$ and the ammonium effluxes that this temperature effect can be applied to the partitioning of total nitrate reduction.

Use of Eq. (4) in the diagenetic model has been shown to be an effective way to simulate observed rates of $D_{\mathrm{w}}$. The same equation can be used to model rates of $\mathrm{DNRA}_{\mathrm{w}}$ which compare well to calculated rates. This represents a first attempt to simulate DNRA in a diagenetic model. Future models will need to rely on more mechanistic equations (which require more detailed work on the underlying microbiology and kinetics) to describe the proportioning of nitrate reduction into denitrification and DNRA. Until such detailed experimental work is done, the work presented here shows that a simple model can be used to interpret field observations. Furthermore, the simplicity of this modelling approach is highlighted in the fact that only 1 free parameter $\left(k_{\mathrm{NO}_{3}}\right)$ needs to be fitted.

It is concluded that over the measured temperature range ( 5 to $22^{\circ} \mathrm{C}$ ) in the lower Gt. Ouse sediments, temperature is an important control in partitioning nitrate reduction into denitrification and DNRA. The narrowness of the temperature range suggests that there is an overlap in the 2 pathways which is indicated by the fact that $P_{\mathrm{D}}$ is never equal to 1 or 0 . Thus, both pathways occur to varying degrees at all temperatures in the lower Gt. Ouse sediments.

Overall, the implication is that during an extended warm summer in temperate estuaries receiving high nitrate inputs, nitrate reduction may contribute to, rather than counteract, a eutrophication event. The conversion of nitrate to the more biologically preferred form of the nitrogen nutrient, ammonium, means that nitrate reduction has considerable fertilising potential. This implication acts as a caveat for studies which concentrate solely on 1 aspect of nitrate reduction (i.e. denitrification) with respect to nitrogen inputs. The search for similar relationships from other data sets must be continued before general conclusions about the response of nitrate reduction to temperature (and other environmental factors) can be made.

Finally, it is concluded that diagenetic models of the nitrogen cycle can and should include DNRA.

Acknowledgements. This work was part of the JoNuS-SONUS (Joint Nutrient Study-Southern Nutrient Study) programme funded by the UK Ministry of Agriculture, Fisheries and Food and Department of the Environment, Transport and the Regions. The views expressed are those of the authors and do not reflect the policies of the funding departments. We thank 3 anonymous referees for helping to improve the quality of this paper.

\section{LITERATURE CITED}

Aller R, Aller J (1998) The effect of biogenic irrigation intensity and solute exchange on diagenetic reaction rates in marine sediments. J Mar Res 56:905-936

Andersen FO (1996) Fate of organic carbon added asa diatom cells to oxic and anoxic marine sediment microcosms. Mar Ecol Prog Ser 134:225-233

Berner RA (1980) Early diagenesis - a theoretical approach. Princeton University Press, Princeton, NJ

Boudreau BP (1995) A method of lines code for carbon and nutrient diagenesis in aquatic sediments. Comp Geosci 22: 479-496

Cole JA, Brown CM (1980) nitrite reduction to ammonia by fermentative bacteria: a short circuit in the biological nitrogen cycle. FEMS Microbiol Lett 7:65-72

Dong L, Thornton D, Nedwell D, Underwood G (2000) Denitrification in sediments of the river Colne estuary, England. Mar Ecol Prog Ser 203:109-122

Gilbert F, Souchu P, Bianchi M, Bonin P (1998) Influence of shell fish farming activities on nitrification, nitrate reduction to amminum and denitrification at the sediment-water interface of the Thau lagoon, France. Mar Ecol Prog Ser 151:143-153

Goeyens L, Devries R, Bakker J, Helder W (1987) An experiment on the relative importance of denitrification, nitrate reduction and ammonification in coastal marine sediment. Neth J Sea Res 21:171-175

Herbert R (1982) Nitrate dissimilation in marine and estuarine sediments. In: Nedwell D, Brown C (eds) Sediment Microbiology. Academic Press, London, p 53-71

Herbert RA, Nedwell DB (1990) Role of environmental factors in regulating nitrate respiration in intertidal sediments. In: Revsbech NP, Sørensen J (eds) Denitrification in soil and sediment. Plenum Press, New York, p 77-90

Hydes D, Kelly-Gerreyn B, Le Gall A, Proctor R (1999) The balance of supply of nutrients and demands of biological production and denitrification in a temperate latitude shelf sea-a treatment of the southern North Sea as an extended estuary. Mar Chem 68:117-131

Jørgensen B, Sørensen J (1985) Seasonal cycles of $\mathrm{O}_{2}, \mathrm{NO}_{3}$ and $\mathrm{SO}_{4}{ }^{2-}$ reduction in estuarine sediments; the significance of an $\mathrm{NO}_{3}{ }^{-}$reduction maximum in spring. Mar Ecol Prog Ser 24:65-74

Jørgensen K (1989) Annual pattern of denitrification and nitrate ammonification in estuarine sediment vacate. Appl Environ Microbiol 55:1841-1847

Jørgensen KS, Sørensen J (1988) Two annual maxima of nitrate reduction and denitrification in estuarine sediment (Norsminde Fjord, Denmark). Mar Ecol Prog Ser 48: 147-154 
Kaspar H (1983) Denitrification, nitrate reduction to ammonium, and inorganic nitrogen pools in intertidal sediments. Mar Biol 74:133-139

Kaspar H, Asher R, Boyer I (1985) Microbial nitrogen transformations in sediments and inorganic nitrogen fluxes across the sediment/water interface on the South Island west coast, New Zealand. Estuar Coast Shelf Sci 21: 245-255

Kelly-Gerreyn B, Hydes D, Trimmer M, Nedwell D (1999) Calibration of an early diagenesis model for high nitrate, low reactive sediments in a temperate latitude estuary. Mar Ecol Prog Ser 177:37-50

Kim DH, Matsuda O, Yamamoto T (1997) Nitrification, denitrification and nitrate reduction rates in the sediment of Hiroshima Bay, Japan. J Oceanogr 53:317-324

King D, Nedwell D (1984) Changes in nitrate-reducing community of an anaerobic saltmarsh sediment in response to seasonal selection by temperature. J Gen Microbiol 130: 2935-2941

King D, Nedwell DB (1987) The adaptation of nitrate-reducing bacterial communities in estuarine sediments in response to overlying nitrate load. FEMS Microbiol Ecol 45:15-20

Koike I, Hattori A (1978) Denitrification and ammonia formation in anaerobic coastal sediments. Appl Environ Microbiol 35:278-282

Koike I, Sørensen J (1988) Nitrate reduction and denitrification in marine sediments. In: Blackburn T, Sørensen J (eds) Nitrogen cycling in coastal and marine environments. J Wiley \& Sons, Chichester, p 215-273

Knowles (1990) Acetylene inhibition technique: development, advantages and potential problems. In: Revsbech $\mathrm{N}$, Sørensen J (eds) Denitrification in soil and sediment. Plenum Press, New York, p 151-166

Lohse L, Epping E, Helder W, van Raaphorst W (1996) Oxygen porewater profiles in continental shelf sediments of the North Sea: turbulent versus molecular diffusion. Mar Ecol Prog Ser 145:63-75

McNichol A, Lee C, Druffel E (1988) Carbon cycling in coastal sediments. I. A quantitative estimate of the remineralisation of organic carbon in the sediments of Buzzards Bay, Mass. Geochim Cosmochim Acta 52:1531-1543

Middelburg JJ, Klaver G, Nieuwenhuize J, Wielemaker A, de Haas W, Vlug T, van der Nat JFWA (1996) Organic mineralisation in intertidal sediments along an estuarine gradient. Mar Ecol Prog Ser 132:157-168

Middelburg JJ, Soetaert K, Herman PMJ, Heip CHR (1996) Denitrification in marine sediments: a model study. Global Biogeochem Cycles 10:661-673

Nedwell DB, Trimmer M (1996) Nitrogen fluxes through the upper estuary of the Great Ouse, England: the role of the bottom sediments. Mar Ecol Prog Ser 142:273-286

Nishio T, Koike I, Hatori A (1983) Estimates of denitrification

Editorial responsibility: Otto Kinne (Editor),

Oldendorf/Luhe, Germany and nitrification in coastal and estuarine sediments. Appl Environ Microbiol 45:444-450

Ogilvie B, Rutter M, Nedwell D (1997a) Selection by temperature of nitrate reducing bacteria from estuarine sediments: species composition and competition for nitrate. FEMS Microbiol Ecol 23:11-22

Ogilvie B, Nedwell D, Harrison R, Robinson A, Sage A (1997b) High nitrate, muddy estuaries as nitrogen sinks: the nitrogen budget of the River Colne estuary (UK). Mar Ecol Prog Ser 150:217-228

Rehr B, Klemme JH (1989) Competition for nitrate between denitrifying Pseudomonas stutzeri and nitrate ammonifying enterobacteria. FEMS Microbiol Ecol 62:51-58

Rysgaard S, Risgaardpetersen N, Nielsen L, Revsbech N (1993) Nitrification and denitrification in lake and estuarine sediments measured by the n-15 dilution technique and isotope pairing. Appl Environ Microbiol 59: 2093-2098

Seitzinger S (1988) Denitrification in freshwater and coastal marine ecosystems: ecological and geochemical perspectives. Limnol Oceanogr 33:702-724

Seitzinger S, Nielsen L, Caffrey J, Christensen P (1993) Denitrification measurements in aquatic sediments - a comparison of 3 methods. Biogeochemistry 23:147-167

Soetaert K, Herman PMJ, Middelburg JJ (1996) A model of early diagenetic processes from the shelf to abyssal depths. Geochim Cosmochim Acta 60:1019-1040

Sørensen J (1978) Capacity for denitrification and reduction of nitrate to ammonia in a coastal marine sediment. Appl Environ Microbiol 35:301-305

Tiedje J (1988) Ecology of denitrification and dissimilatory nitrate reduction to ammonium. In: Zehnder A (ed) Biology of Anaerobic Microorganisms. J. Wiley \& Sons, New York, p 179-244

Trimmer T (1997) The role of bottom sediments in the nitrogen budget of the Great Ouse estuary. $\mathrm{PhD}$ thesis, University of Essex

Trimmer M, Nedwell DB, Sivyer DB, Malcolm SJ (1998) Nitrogen fluxes through the lower estuary of the river Gt. Ouse, England: the role of the bottom sediments. Mar Ecol Prog Ser 163:109-124

van Raaphorst W, Kloosterhuis H, Berguis E, Gieles A, Malschaert J, van Noort G (1992) Nitrogen cycling in two banks of sediments in the southern North Sea (Frisian Front, Broad Fourteens): field data and mesocosm results. Neth J Sea Res 28:293-316

Wang Y, Van Cappellan P (1996) A multipcomponent reactive transport model of early diagenesis: application to redox cycling in coastal marine sediments. Geochim Cosmochim Acta 60:2993-3014

Wilson T (1975) Salinity and major elements of seawater. In: Liley J, Skirrow G (eds) Chemical oceanography, Vol 1. Academic Press, London, p 365-413

Submitted: December 7, 2000; Accepted: July 17, 2001

Proofs received from author(s): September 4, 2001 